\title{
A Case of Lobulated and Pedunculated Duodenal Hyperplastic Polyp Treated with Snare Polypectomy
}

\author{
Hideto Kawaratani ${ }^{a}$ Tatsuhiro Tsujimoto ${ }^{a, b}$ \\ Norihisa Nishimura ${ }^{a}$ Tomoyasu Taniguchi $^{a}$ \\ Yusaku Shirai ${ }^{a}$ Kenichi Kin ${ }^{a}$ Masaki Nakayamac \\ Hisao Fujii ${ }^{b}$ Hiroshi Fukui ${ }^{\mathrm{a}}$
}

${ }^{\mathrm{a}}$ Third Department of Internal Medicine and ${ }^{\mathrm{b}}$ Department of Endoscopy and Ultrasound, Nara Medical University, Kashihara, and 'Department of Internal Medicine, West Nara Central Hospital, Nara, Japan

\section{Key Words}

Duodenal hyperplastic polyp · Capsule endoscopy · Endoscopic snare polypectomy

\begin{abstract}
We report herein the case of a lobulated and pedunculated hyperplastic polyp in the third portion of the duodenum causing anemia and occult blood in stools, which was detected by capsule endoscopy (CE) and treated with snare polypectomy. A 71-year-old man was referred to our hospital because of anemia and occult blood in stools. Three months earlier, he had been admitted to another hospital because of hemorrhage from gastric antral vascular ectasia (GAVE). Despite being treated for GAVE, hemoglobin decreased gradually. Esophagogastroduodenoscopy (EGD) and colonoscopy revealed no source of bleeding. However, CE revealed a polyp at the distal duodenum. Barium meal and EGD revealed a lobulated and pedunculated polyp in the third portion of the duodenum. The polyp was treated with snare polypectomy. Histopathological examination of the polyp revealed hyperplasia. After treatment of the polyp, the anemia improved gradually. To our knowledge, there are only 6 reported cases of a duodenal hyperplastic polyp, including our case. The polyp was pedunculated in only 2 cases and lobulated only in our case. Moreover, our case was diagnosed by CE. When a patient presents with anemia or obscure gastrointestinal bleeding undiagnosed by EGD and colonoscopy, CE is useful for detecting the bleeding lesion.
\end{abstract}




\section{Introduction}

As technological advancements have been made in endoscopy, the occurrence of duodenal tumors has increased. But when we examine patients by endoscopy, tumors of the duodenum are not often diagnosed. Their prevalence is reportedly about $4.6 \%$ [1]. Most duodenal tumors of the first portion are benign, but the incidence of malignancy increases as they are more distally located. The ratio of malignant to benign tumors is about 1.2:1. The main malignant tumors of the duodenum are carcinomas. On the other hand, the main benign tumors of the duodenum are adenoma and Brunner's gland hyperplasia, but hyperplastic polyp is rare. Both malignant and benign tumors of the duodenum tend to occur in the middle or older age groups.

A polyp is defined as an abnormal growth of tissue projecting from a mucous membrane. The prevalence of duodenal polyps is estimated to be about $1 \%$ in patients referred for esophagogastroduodenoscopy (EGD). Duodenal polyps are commonly sessile and may also be pedunculated in nature. Most duodenal polyps are inflammatory polyps, Brunner's gland hyperplasia and have ectopic gastric mucosa. Hyperplastic polyps usually occur in the setting of ectopic gastric mucosa and have an appearance that more closely mimics hyperplastic polyps of the gastric than the colonic type.

The clinical symptoms of duodenal tumors are abdominal pain, vomiting, melena, fever and diarrhea, and sometimes they are asymptomatic. However, there are no specific symptoms of duodenal tumors. The treatments of duodenal tumors are various. Most duodenal polyps less than $1 \mathrm{~cm}$ in size do not require treatment if biopsy specimen is consistent with a benign tumor. Pedunculated polyps have been managed with polypectomy, mainly by endoscopic treatment. Sessile polyps larger than $2 \mathrm{~cm}$, not specifically diagnosed by biopsy specimen, are excised during the operation.

Recently, capsule endoscopy (CE) and single- or double-balloon enteroscopy (SBE or DBE) have been developed and employed in clinical practice. CE and SBE or DBE can reveal bleeding lesions or tumors in the small intestine, which could not be detected by EGD and colonoscopy. Furthermore, approximately $5 \%$ of patients with gastrointestinal bleeding exhibit no identifiable source by upper endoscopy and colonoscopy. The cause of obscure gastrointestinal bleeding (OGIB) is usually a lesion located in the small bowel, but also includes lesions that were overlooked during conventional endoscopy. The incidence of duodenal tumors detected by CE has not been confirmed.

To our knowledge, only 5 cases of a duodenal hyperplastic polyp detected by EGD have been reported, but this is the first case of a polyp detected by CE. We excised the polyp with snare polypectomy. In this report, we describe the case of a lobulated and pedunculated duodenal hyperplastic polyp detected by CE and treated with polypectomy, and present a review of the literature.

\section{Case Report}

A 71-year-old man was referred to our hospital in the middle of November 2009 for thorough investigation of asymptomatic iron deficiency anemia and occult blood in stools. He had a past history of tuberculosis about 40 years earlier. No specific family history was identified. He had gone to another hospital for hypertension and constipation. Three months before, he was admitted to hospital because of tarry stools. Emergency EGD revealed gastric antral vascular ectasia (GAVE) in the antrum of the 
stomach. There were many coagula on GAVE, and these were thought to be the cause of tarry stool. Argon plasma coagulation treatment was performed on the 6th day of admission. Directly after argon plasma coagulation treatment, tarry stools disappeared. Follow-up EGD 1 week later revealed no bleeding lesion along with improvement of GAVE, and the patient was discharged. Subsequently, his hemoglobin $(\mathrm{Hb})$ level gradually decreased within 3 months (from 9.7 to $7.9 \mathrm{~g} / \mathrm{dl}$ ), but he had no symptoms. As the test for occult blood in stools was positive, EGD and colonoscopy were performed. EGD revealed improvement of GAVE and there were no signs of bleeding. Meanwhile, colonoscopy revealed diverticula but no bleeding lesions. In late November 2009, we performed CE to detect the source of occult blood in stools. CE revealed a tumor-like lesion at the distal duodenum (fig. 1) and angiodysplasia at the end of the jejunum. Angiodysplasia was very small and appeared not to be the source of bleeding. We re-examined the distal duodenum by EGD. A large lobulated polyp about $2.5 \mathrm{~cm}$ in diameter, with a long stem, was detected in the third portion of the duodenum (fig. 2). The surface of the polyp was reddish and thought to be the cause of anemia. An air-contrast barium meal also revealed a lobulated and pedunculated polyp in the third portion of the duodenum.

Physical examination on admission revealed a well-developed, well-nourished man, and vital signs were normal. Laboratory examinations were as follows: $\mathrm{Hb} 7.9 \mathrm{~g} / \mathrm{dl}$, serum iron concentration $44 \mu \mathrm{g} / \mathrm{dl}$, ferritin $57.8 \mathrm{ng} / \mathrm{ml}$. After admission in early January 2010, endoscopic snare polypectomy was performed. The resected polyp was excised without bleeding. The cut surface of the resected specimen was clear. The polyp was $27 \mathrm{~mm}$ in diameter and histological examination showed an area of elongated crypts and villi with focal gastric-type surface epithelium. Epithelial nuclear atypia was present at the base of the crypts, but this feature was generally less marked at the surface (fig. 3 ). Five days after polypectomy, EGD showed no bleeding, and the patient was discharged. After treatment, his $\mathrm{Hb}$ level improved gradually (from 7.9 to $14.2 \mathrm{~g} / \mathrm{dl}$ ) and did not decrease for 6 months.

\section{Discussion}

When we examine patients by endoscopy, duodenal tumors are sometimes seen. EGD is considered the gold standard for diagnosing tumors because biopsies can be obtained. The main benign tumors of the duodenum are adenoma and Brunner's gland hyperplasia, but hyperplastic polyps are rare [2]. Duodenal tumors are often insidious with non-specific symptoms such as abdominal pain, anemia, and gastrointestinal bleeding. Small and non-pedunculated hyperplastic polyps are sometimes seen in the bulb of the duodenum [3], but large and pedunculated polyps are reportedly very rare. The risk of development of focal adenocarcinoma in a hyperplastic polyp of the stomach is less than 1\% [4]. Similarly, the malignant potential of duodenal hyperplastic polyp is thought to be very minimal. Histological examination of those polyps following snare polypectomy shows no malignancy.

In some patients with gastrointestinal tract bleeding of unknown origin, diagnosis cannot be made after EGD and colonoscopy. However, detection of the bleeding point recently has been enabled by the use of CE, SBE or DBE [5]. Nonetheless, CE sometimes overlooks small intestinal tumors [6]. CE, SBE and DBE have mainly been used to investigate OGIB, polyposis syndromes, Crohn's disease, and celiac disease [7]. Although $\mathrm{CE}$ is used mainly to investigate the jejunum and ileum, duodenal tumors are occasionally detected.

Classification of gastric polyps has been previously discussed [8]. Currently, epithelial gastric polyps are mainly divided into hyperplastic, adenomatous or fundic gland polyps [9]. The microscopic features of gastric hyperplastic polyps consist of branching or elongated hyperplastic glands [10]. However, the genesis of duodenal hyperplastic polyps has not been clarified yet. Focal foveolar hyperplasia and 
pyloric-type glandular hyperplasia have been reported [11], but there is some confusion in the literature concerning duodenal hyperplastic polyps.

Our review of the medical literature in PubMed between 1975 and 2010 revealed 5 cases of duodenal hyperplastic polyps [11-15]. The details of all 6 reported cases, including our present case, are shown in table 1. There were 4 males and 2 females, and their mean age was 50.5 years (range $2-79$ years). The most commonly presenting symptom was anemia. Upper gastrointestinal series was performed in 3 cases, while EGD was performed in all of them. The characteristics of EGD findings are variable. The location of the polyp was the bulb in 4 cases. The size varied greatly from $3 \mathrm{~mm}$ to $6 \mathrm{~cm}$. The shape was pedunculated in only 2 cases. Polyps were mostly solitary, and a lobulated polyp was detected only in our case. Histology revealed a hyperplastic polyp with no atypical cells in 5 cases and a hyperplasiogenic polyp with atypical cells in 1 case. There were no malignancies. Two cases underwent polypectomy and 1 case underwent surgery. The outcome was good with improvement of anemia in 2 cases and disappearance of the symptoms in 1 case. In our case only, the polyp, which was located in the third portion of the duodenum, was pedunculated and lobulated. Moreover, our case is the only one that underwent CE. Since a duodenal hyperplastic polyp is thought to have a minimal risk of malignancy, endoscopic treatment is effective for treatment of patients with anemia or abdominal symptoms from a duodenal polyp.

In conclusion, in this report we presented the unique case of a lobulated and pedunculated hyperplastic polyp of the duodenum that was detected by $\mathrm{CE}$ and successfully treated with endoscopic snare polypectomy. CE is useful in detecting the bleeding lesion when patients present with anemia and OGIB undetected by EGD and colonoscopy.

\section{Disclosure Statement}

There are no conflicts of interest to disclose. 


\begin{tabular}{r|l|l|l}
$\begin{array}{r}\text { Case Reports in } \\
\text { Gastroenterology }\end{array}$ & $\begin{array}{l}\text { Case Rep Gastroenterol 2011;5:404-410 } \\
\text { Dol: } 10.1159 / 000330477\end{array}$ & $\begin{array}{l}\text { Published online: } \\
\text { July 21, 2011 }\end{array}$ & $\begin{array}{l}\odot \text { 2011 S. Karger AG, Basel } \\
\text { ISSN 1662-0631 } \\
\text { www.karger.com/crg }\end{array}$ \\
\hline
\end{tabular}

Table 1. Reported cases of duodenal hyperplastic polyps

\begin{tabular}{|c|c|c|c|c|c|c|c|c|c|c|c|}
\hline Reference & Age & Sex & $\begin{array}{l}\text { Past } \\
\text { history }\end{array}$ & $\begin{array}{l}\text { Presenting } \\
\text { complaints }\end{array}$ & $\begin{array}{l}\text { Polyp } \\
\text { size }\end{array}$ & $\begin{array}{l}\text { Loca- } \\
\text { tion }\end{array}$ & $\begin{array}{l}\text { Endoscopic } \\
\text { findings }\end{array}$ & $\begin{array}{l}\text { UGI series } \\
\text { findings }\end{array}$ & Histological findings & $\begin{array}{l}\text { Treat- } \\
\text { ment }\end{array}$ & Outcome \\
\hline $\begin{array}{l}\text { Remmele } \\
\text { et al. [11] }\end{array}$ & 79 & F & AMI & anemia & n.r. & bulb & one large polyp & n.r. & $\begin{array}{l}\text { hyperplastic polyp with } \\
\text { foveolar hyperplasia and } \\
\text { glands of the pyloric type }\end{array}$ & n.r. & n.r. \\
\hline $\begin{array}{l}\text { Franzin } \\
\text { et al. [12] }\end{array}$ & 51 & M & n.r. & melena & $3 \mathrm{~mm}$ & bulb & $\begin{array}{l}\text { round sessile } \\
\text { pale-pink polyp }\end{array}$ & n.r. & $\begin{array}{l}\text { hyperplastic epithelium } \\
\text { of the intestinal type }\end{array}$ & none & n.r. \\
\hline $\begin{array}{l}\text { Roesch } \\
\text { and Hoeer } \\
{[13]}\end{array}$ & 42 & $\mathrm{~F}$ & n.r. & $\begin{array}{l}\text { abdominal } \\
\text { discomfort }\end{array}$ & n.r. & $\begin{array}{l}\text { bulb } \\
\text { and } \\
\text { second } \\
\text { portion }\end{array}$ & $\begin{array}{l}\text { broad bed of } \\
\text { multiple polyps } \\
\text { resembling ectopic } \\
\text { mucosa }\end{array}$ & $\begin{array}{l}\text { multiple } \\
\text { polyps }\end{array}$ & hyperplasiogenic polyp & $\begin{array}{l}\text { polypec- } \\
\text { tomy }\end{array}$ & $\begin{array}{l}\text { symptoms } \\
\text { disap- } \\
\text { peared }\end{array}$ \\
\hline $\begin{array}{l}\text { Verhage } \\
\text { et al. [14] }\end{array}$ & 2 & M & none & anemia & $6 \times 3 \mathrm{~cm}$ & bulb & $\begin{array}{l}\text { a large polyp with } \\
\text { easily hemorrhagic } \\
\text { mucosa }\end{array}$ & $\begin{array}{l}\text { hyperplastic } \\
\text { polyp }\end{array}$ & $\begin{array}{l}\text { juvenile hyperplastic } \\
\text { polyp }\end{array}$ & operation & $\begin{array}{l}\text { improve- } \\
\text { ment of } \\
\text { anemia }\end{array}$ \\
\hline $\begin{array}{l}\text { Roche } \\
\text { et al. [15] }\end{array}$ & 58 & M & $\begin{array}{l}\text { Barrett's } \\
\text { esopha- } \\
\text { gus }\end{array}$ & n.r. & n.r. & $\begin{array}{l}\text { distal } \\
\text { duode- } \\
\text { num }\end{array}$ & $\begin{array}{l}\text { white ridges on the } \\
\text { top of the mucosal } \\
\text { folds }\end{array}$ & n.r. & $\begin{array}{l}\text { elongated crypts and villi } \\
\text { with serrated profiles, } \\
\text { similar to a hyperplastic } \\
\text { polyp of the colon }\end{array}$ & n.r. & n.r. \\
\hline $\begin{array}{l}\text { This } \\
\text { report }\end{array}$ & 71 & M & $\begin{array}{l}\text { Tbc, } \\
\text { hyper- } \\
\text { tension }\end{array}$ & anemia & $27 \mathrm{~mm}$ & $\begin{array}{l}\text { third } \\
\text { portion }\end{array}$ & $\begin{array}{l}\text { lobulated polyp } \\
\text { with long stem }\end{array}$ & $\begin{array}{l}\text { lobulated and } \\
\text { pedunculated } \\
\text { polyp }\end{array}$ & $\begin{array}{l}\text { elongation of crypts and } \\
\text { villi with focally gastric- } \\
\text { type surface epithelium }\end{array}$ & $\begin{array}{l}\text { polypec- } \\
\text { tomy }\end{array}$ & $\begin{array}{l}\text { improve- } \\
\text { ment of } \\
\text { anemia }\end{array}$ \\
\hline
\end{tabular}

$\mathrm{AMI}=$ Acute myocardial infarction; n.r. = not recorded; Tbc = tuberculosis; UGI = upper gastrointestinal

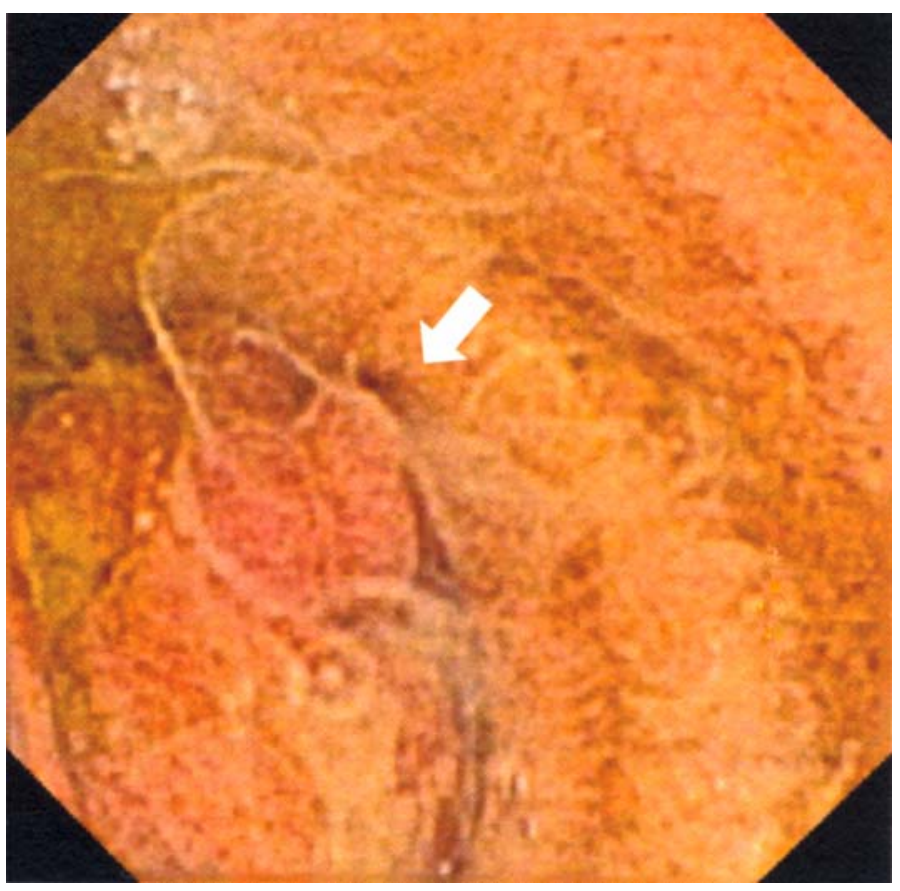

Fig. 1. CE findings. A tumor-like lesion was seen in the distal duodenum (white arrow). 


\begin{tabular}{|c|c|c|c|}
\hline $\begin{array}{l}\text { Case Reports in } \\
\text { Gastroenterology }\end{array}$ & \begin{tabular}{|l} 
Case Rep Gastroenterol 2011;5:404-410 \\
DOl: 10.1159/000330477
\end{tabular} & $\begin{array}{l}\text { Published online: } \\
\text { July 21, } 2011\end{array}$ & $\begin{array}{l}\text { O } 2011 \text { S. Karger AG, Basel } \\
\text { ISSN 1662-0631 } \\
\text { www.karger.com/crg }\end{array}$ \\
\hline
\end{tabular}

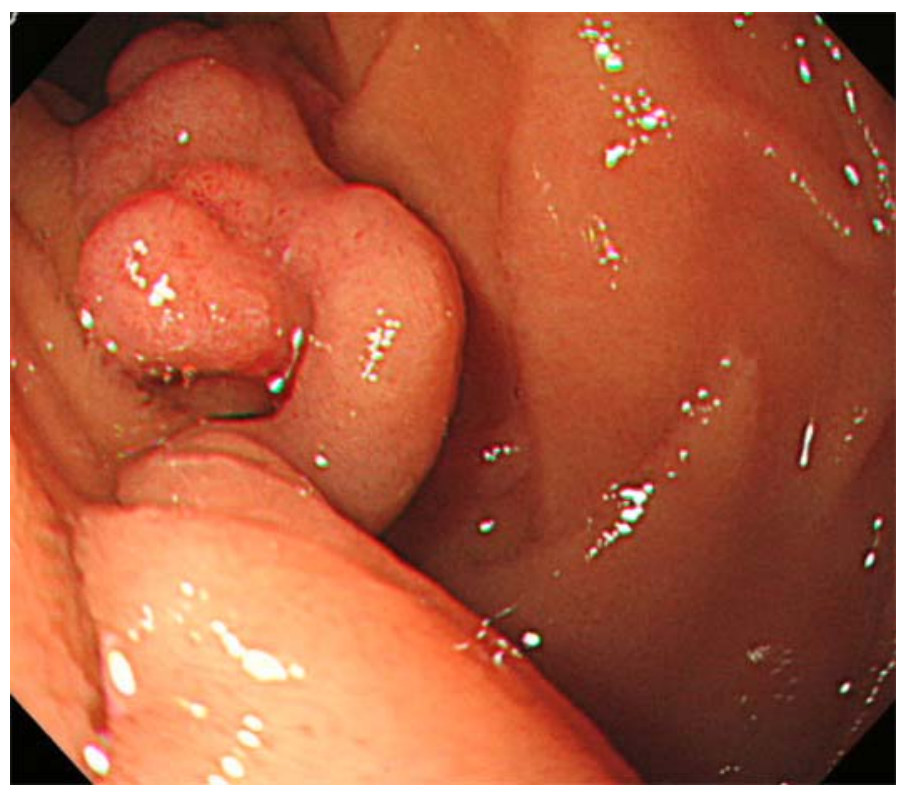

Fig. 2. EGD findings. A large lobulated and pedunculated polyp was seen in the third portion of the duodenum.

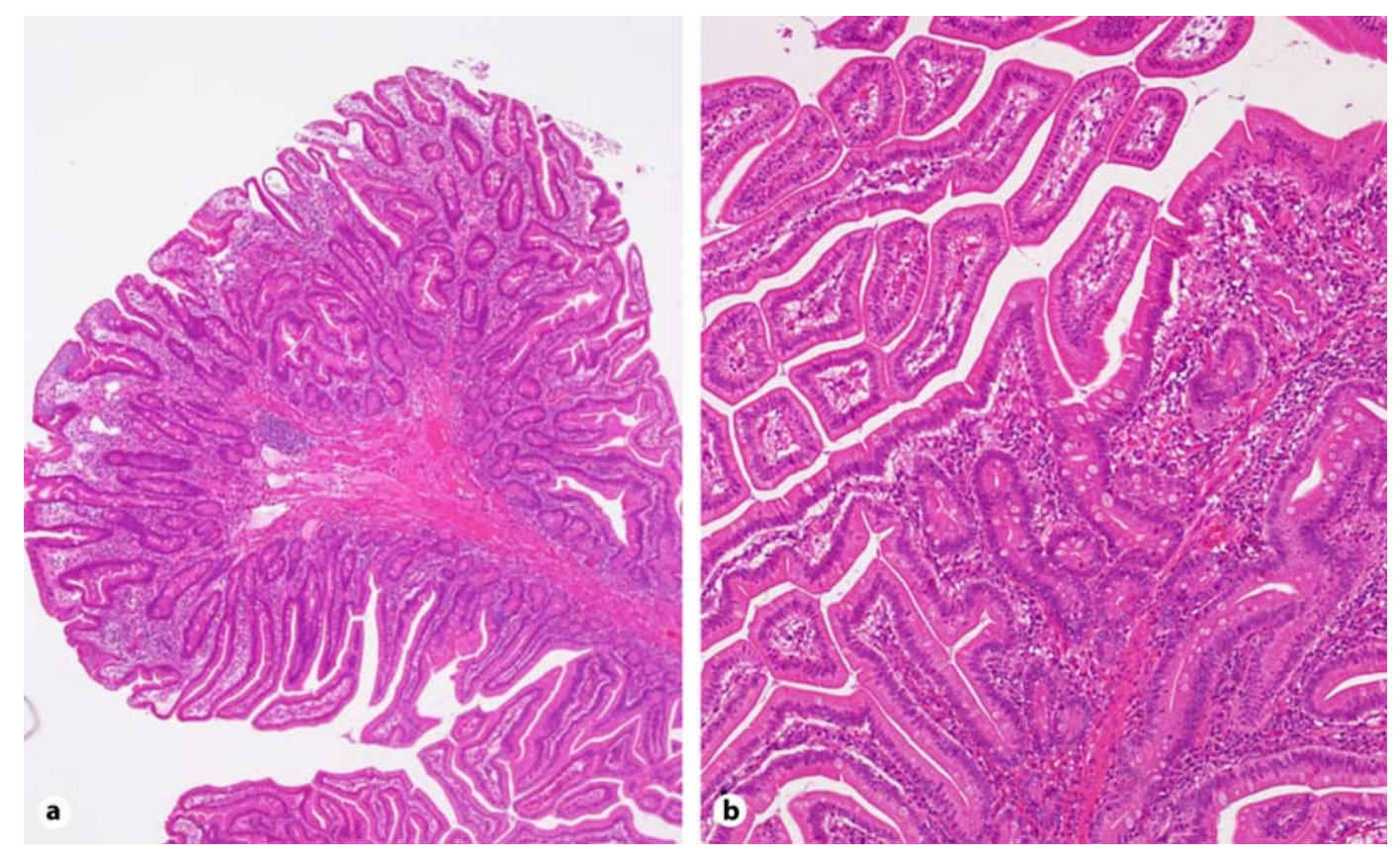

Fig. 3. Histopathological findings. The duodenal mucosa is polypoid and shows elongation of crypts and villi with focal gastric-type surface epithelium. H\&E stain, $\times 20(\mathbf{a}), \times 100(\mathbf{b})$. 


\begin{tabular}{|c|c|c|c|}
\hline $\begin{array}{r}\text { Case Reports in } \\
\text { Gastroenterolooy }\end{array}$ & $\begin{array}{l}\text { Case Rep Gastroenterol 2011;5:404-410 } \\
\text { DOI: } 10.1159 / 000330477\end{array}$ & $\begin{array}{l}\text { Published online: } \\
\text { July 21, } 2011\end{array}$ & $\begin{array}{l}\text { () } 2011 \text { S. Karger AG, Basel } \\
\text { ISSN } 1662-0631 \\
\text { www.karger.com/crg }\end{array}$ \\
\hline
\end{tabular}

\section{References}

$\longrightarrow 1$ Jepsen JM, Persson M, Jakobsen NO, et al: Prospective study of prevalence and endoscopic and histopathologic characteristics of duodenal polyps in patients submitted to upper endoscopy. Scand J Gastroenterol 1994;29: 483-487.

-2 Matsui K, Kitagawa M: Biopsy study of polyps in the duodenal bulb. Am J Gastroenterol 1993;88:253-257.

-3 Matsuura H, Kuwano H, Kanematsu T, Sugimachi K, Haraguchi Y: Clinicopathological feature of elevated lesion of the duodenal bulb. J Surg Oncol 1990;45:79-84.

4 Nakamura T, Nakano G: Histopathological classification and malignant change in gastric polyps. J Clin Pathol 1985;38:754-764.

5 Tsujikawa T, Saitoh Y, Andoh A, et al: Novel single-balloon enteroscopy for diagnosis and treatment of the small intestine: preliminary experiences. Endoscopy 2008;40:11-15.

-6 Postgate A, Despott E, Burling D, et al: Significant small-bowel lesions detected by alternative diagnostic modalities after negative capsule endoscopy. Gastrointest Endosc 2008;68:1209-1214.

7 Varela Lema L, Ruano-Ravina A: Effectiveness and safety of capsule endoscopy in the diagnosis of small bowel diseases. J Clin Gastroenterol 2008;42:466-471.

8 Elster K: A new approach to the classification of gastric polyps. Endoscopy 1974;6:44-47.

9 Goddard AF, Badreldin R, Pritchard DM, Walker MM, Warren B; British Society of Gastroenterology: The management of gastric polyps. Gut 2010;59:1270-1276.

10 Burke CA, van Stolk RU: Diagnosis and management of gastroduodenal polyps. Surg Oncol Clin N Am 1996;5:589-607.

11 Remmele W, Hartmann W, von der Laden U, et al: Three other types of duodenal polyps: mucosal cysts, focal foveolar hyperplasia, and hyperplastic polyp originating from islands of gastric mucosa. Dig Dis Sci 1989;34: $1468-1472$.

12 Franzin G, Novelli P, Fratton A: Hyperplastic and metaplastic polyps of the duodenum. Gastrointest Endosc 1983;29:140-142.

13 Roesch W, Hoeer PW: Hyperplasiogenic polyp in the duodenum. Endoscopy 1983;15:117-118.

14 Verhage J, Mulder CJ, Meyer JW, Reuvers CB: Hyperplastic duodenal polyp in a boy. J Pediatr Gastroenterol Nutr 1994;19:326-328.

15 Roche HJ, Carr NJ, Laing H, Bateman AC: Hyperplastic polyps of the duodenum: an unusual histological finding. J Clin Pathol 2006;59:1305-1306. 